Indonesian Journal of Biotechnology, June, 2014

Vol. 19, No. 1, pp.71-78

\title{
Cytotoxicity of Buah Merah (Pandanus conoideus Lamk.) Extract on Breast Cancer Cell Line (T47D)
}

\author{
Tri R Nuringtyas ${ }^{1 *}$, Yoga Pratama ${ }^{1}$, Galih $^{1}$, Subagus Wahyuono², \\ and Sukarti Moeljopawiro ${ }^{1}$
}

${ }^{1}$ Faculty of Biology, Gadjah Mada University, Yogyakarta, Indonesia, Jalan Teknika Selatan Sekip Utara,
Yogyakarta 55281
${ }^{2}$ Faculty of Pharmacy, Gadjah Mada University, Yogyakarta, Indonesia, Sekip Utara, Yogyakarta
55281

\begin{abstract}
Buah Merah (Pandanus conoideus Lamk.) has been extensively used to treat various diseases including cancer. There are many varieties of buah merah and there was no scientific study comparing cytotoxicity of different varieties. The objective of this study was to investigate the cytotoxicity of three varieties of buah merah known as Barugum, Maler and Yanggiru on breast cancer cell line (T47D). All samples were collected from Papua, Indonesia. Each sample was extracted consecutively using three solvents chloroform, methanol and water resulted to nine crude extracts. The cytotoxic activities were determined using MTT assay. The crude extract showed the lowest $\mathrm{IC}_{50}$ was selected for further bioassay-guided fractionation. Fractionation was done using vacuum liquid chromatography coupled with preparative TLC to find the active compounds. Several detection reagents were applied to TLC for identification of the class of the potent compounds. The result showed that the potent extracts was obtained from Barugum methanol extract followed by Maler chloroform extract with $\mathrm{IC}_{50}$ value of $132.83 \mu \mathrm{g} / \mathrm{ml}$ and $139.72 \mu \mathrm{g} / \mathrm{ml}$, respectively. All Yanggiru extracts did not show activity. The bioassay-guided fractionation of Barugum and Maler extracts showed that the most potent fraction eluted by a mixture of hexane:ethyl acetate (75:25), was in Maler variety with $\mathrm{IC}_{50}$ value of $25,7 \mu \mathrm{g} / \mathrm{ml}$, four times higher than the most potent fraction of Barugum with $\mathrm{IC}_{50}$ value of $104,61 \mu \mathrm{g} / \mathrm{ml}$. TLC analysis of the most potent fraction showed that the active compounds was class of terpene. Result of this study supported the utilization of buah merah Maler variety for breast cancer treatment.
\end{abstract}

Key words: Buah Merah, cytotoxicity, T47D, vacuum liquid chromatography, thin-layer chromatography

\section{Introduction}

Plants have an almost limitless ability to synthesis bioactive substances. Most are secondary metabolites, of which at least 12.000 have been isolated, a number estimated to be less than $10 \%$ of the total. Only a small percentage of the 400.000 to 500.000 species in the plant kingdom has been phytochemically investigated (Wink, 2003). It

\section{*Corresponding author:}

Tri R. Nuringtyas

Faculty of Biology, Gadjah Mada University, Yogyakarta, Indonesia, Jalan Teknika Selatan Sekip Utara, Yogyakarta 55281, E-mail: tririni@ugm. ac.id is well established that secondary metabolites becomes one of the most important sources of pharmacologically active compounds including for cancer treatment (Cragg et al., 1999).

Breast cancer is the second leading cause of death in women today and is the most common cancer among women. Though much less common, breast cancer also occurs in men. More than a half of breast cancer cases are caused by unknown factors (Madigan et al., 1995). Nevertheless, some risk factors which increase someone's probability of having breast cancer are postmenopausal hormone therapy, exposed to ionizing radiation, alcohol consumption, 
and have $B R C A 1$ and $B R C A 2$ mutant genes (Longnecker et al., 1995 and Hortobagyi, 1998). The probability of a woman with the mutant genes to has breast cancer is $50-85 \%$ (Hedenfalk et al., 2001).

Different techniques can be used for the chemical evaluation of plants. Bioassayguided fractionation using vacuum column chromatography (VLC) coupled with preparative Thin-layer chromatography (TLC) considers as the simplest and cheapest method. Cytotoxic screening models provide important preliminary data to select plant extracts with potential anti-cancer properties. The most commonly cytotoxic assay used is MTT (3-(4,5-dimethylthiazol-2-yl)-2,5diphenyl tetrazolium bromide) assay.

Buah merah (Pandanus conoideus Lamk.) grows naturally in Papua, Indonesia at 1,2002,000 $\mathrm{m}$ above sea level (Anonim, 2005). Recently, buah merah has been extensively used to treat HIV/AIDS, diabetes mellitus, gout and rheumatism, osteoporosis, and cancer. According to Moeljopawiro et al. (2007), extracts of buah merah have ability to inhibit breast, cervical and colon cancer cells proliferation. The scientific studies of anticancer activity of buah merah on the growth of cancer cells are relatively very few. In Papua, several varieties of buah merah are observed and so far there were no study comparing the cytotoxicity among these varieties. Therefore, the objective of this research was to study the cytotoxicity of three varieties of buah merah known as Barugum, Maler and Yanggiru and determine the group of bioactive compounds.

\section{Materials And Methods}

Three varieties of buah merah including Barugum, Maler, and Yanggiru, collected from Sentani, Jayapura, Papua, Indonesia were used in this study. The breast cancer cell line used was T47D. This cell line was obtained from a cell culture continually grown at the Laboratorium Penelitian dan Pengujian Terpadu (LPPT) UGM. Doxorubicin (Ebewe), was used as a reference on cytotoxic assay.

\section{Extraction of Samples}

All samples were extracted using three solvents including chloroform (Merck), methanol (Merck), water.Thirty five gram of fresh fruit for each variety was consecutively extracted using Soxhlet apparatus (Pyrex) at $65^{\circ} \mathrm{C}$ with $250 \mathrm{ml}$ of solvent. Initially, chloroform was used as a solvent and resulted residue was then extracted using methanol. Finally, water was used for the last extraction. Each extract was evaporated to dryness under reduced pressure on rotary evaporator (Rotavapor, Buchi) and was stored at $4^{\circ} \mathrm{C}$ for further use.

\section{Cytotoxic Assay (Mosmann, 1983)}

In preliminary experiments a serial concentration of $0-500 \mu \mathrm{g} / \mathrm{ml}$ of methanol extracts of buah merah showed a clear dose response with cell mortality. Therefore this concentration range was used in later experiments.

An aliquot of $100 \mu \mathrm{l}$ cell suspension $( \pm$ $1.510^{4}$ cells) was loaded into each well of 96-well microtitre plates and incubated for 24 hours at $37^{\circ} \mathrm{C}, 5 \% \mathrm{CO}_{2}$ to allow for cell attachment. Extracts of buah merah at different concentrations ranging from $0-500 \mu \mathrm{g} / \mathrm{ml}$ were added and then incubated for 24 hours at the same condition. For each concentration tested four replicates were used. Two controls were applied, a control consisting of medium and another control consisting of mixture of DMSO and culture cells. At the end of the treatment, the medium and extracts were then removed and $110 \mu \mathrm{MTT}$ (Sigma) was added. MTT was prepared as $10 \%$ MTT stock solution in culture medium, sterilized by filtration through a $0.2 \mathrm{~mm}$ filter and stored at $2-8^{\circ} \mathrm{C}$. The plate was incubated in the dark for 4 hours. After 4 hours, $100 \mu \mathrm{l}$ stop solution (10\% SDS (Sigma) in $0.1 \mathrm{~N} \mathrm{HCl}$ ) was added in each well and again the plates were then incubated in the dark for overnight at room temperature. The absorbance was recorded using ELISA plate reader (Bio-Rad) at $595 \mathrm{~nm}$. The value of $\mathrm{IC}_{50}$ was determined by probit analysis. 
Nuriningtyas et al.

\section{Bioassay guided Fractionation of Barugum and Maler extracts}

\section{Fractionation}

The active extracts, methanol extract of Barugum and chloroform extract of Maler, were subjected to fractionation by VLC on Sephadex LH-20 (Sigma) using a mixture of different solvents ranging from non polar to polar including hexane, ethyl acetate, chloroform, methanol and water. TLC was performed to monitor the metabolites contained in each fraction. The fractions with similar TLC profiles were combined. Fractionation of methanol extract of Barugum was done using 15 eluents while the chloroform extract of Maler with 6 eluents.

\section{Preparative TLC}

Preparative TLC was performed similarly like the procedure of TLC, except for the stationary phase plates of preparative TLC were silica gel $\mathrm{PF}_{254}$. The plates were developed using a mixture of chloroform : ethyl acetate $=9: 1 \mathrm{v} / \mathrm{v}$. Based on the profile, preparative TLC produced three portions (upper, middle and lower) portions for Barugum and two (upper and lower) portions for Maler. These portions were then subjected to cytotoxic assay to determine the active portion containing the active compounds

\section{Sequence of bioassay-guided fractionation}

Due to different results in the first fractionation of Barugum and Maler, therefore different strategies of fractionation were applied.

a. The combined fraction of the methanol extract of Barugum were directly subjected to cytotoxic assay at a single dose of $250 \mu \mathrm{g} / \mathrm{ml}$ representing a middle concentration on the crude extracts cytotoxic assay. The most potent fraction was selected for further separation using preparative TLC then followed by cytotoxic assay.

b. The two fractions of the chloroform extract of Maler showed similar TLC profile
I.J. Biotech.

therefore these fractions were combined again. Separation was further performed using preparative TLC. The results of the preparative TLC were then subjected to cytotoxic assay. Based on this cytotoxic assay, the most potent portion was further fractionated using 6 eluents. The results of this fractionation were monitored using TLC and the fractions that showed similar TLC profile were combined. This combined fractions were then evaluated the activity using MTT assay.

\section{Identification of Toxic Compounds Classes}

The most toxic fraction obtained from preparative TLC was analyzed by TLC and then visualized by spraying reagents including serium (IV) sulfat, Lieberman-Burchard, vanilin sulfat, Sitroborat, Dragendroff, $\mathrm{FeCl}_{3}$ , jodium and ammonia to identify the groups of compounds.

\section{RESULTS \\ Identification of Samples}

Based on morphological characteristics, buah merah collected from Papua could be classified into three local varieties, Barugum, Maler and Yanggiru with characteristics as described in Table 1. Yanggiru variety has specific yellow color different among the rest varieties. Although both Barugum and Maler have similar color, but the two can be distinguished easiliy by the shape of the fruit. Barugum fruit normally has a bigger fruit and has oblongus triangular in shape while Maler tends to have slimmer oblongus.

\section{Cytotoxicity of Extracts}

Cytotoxicity of 9 crude extracts showed that the water extracts of all samples did not have cytotoxic effect on breast cancer cells. The most toxic extracts with the lowest $\mathrm{IC}_{50}$ value were found on methanol extract of Barugum with $\mathrm{IC}_{50}$ value of $132,83 \mu \mathrm{g} / \mathrm{ml}$, followed by chloroform extract of Maler with $\mathrm{IC}_{50}$ value of $139,72 \mu \mathrm{g} / \mathrm{ml}$ (Table 2 ). These two crude extracts were chosen for further bioassay guided fractionation. The three 
Nuriningtyas et al.

I.J. Biotech.

Table 1. Morphological characteristics of fruits of three local varieties of buah merah

\begin{tabular}{lccc}
\hline \multirow{2}{*}{ Parameters } & \multicolumn{3}{c}{ Varieties } \\
\cline { 2 - 4 } & Barugum & Yanggiru & Maler \\
\hline Size & Big & Small & Medium \\
Shape & Oblongus triangular & Oblongus & Oblongus \\
Length $(\mathrm{cm})$ & 63 & 50 & 65 \\
Base diameter $(\mathrm{cm})$ & 19 & 4 & 12 \\
Tip diameter $(\mathrm{cm})$ & 7 & 4 & 3 \\
Weight $(\mathrm{kg})$ & 11.25 & 3.95 & 5.10 \\
Colour & Red & Yellow & Red
\end{tabular}

Seed position $\quad$ Form irregular rows on Form irregular rows on Form irregular rows the axis the axis on the axis

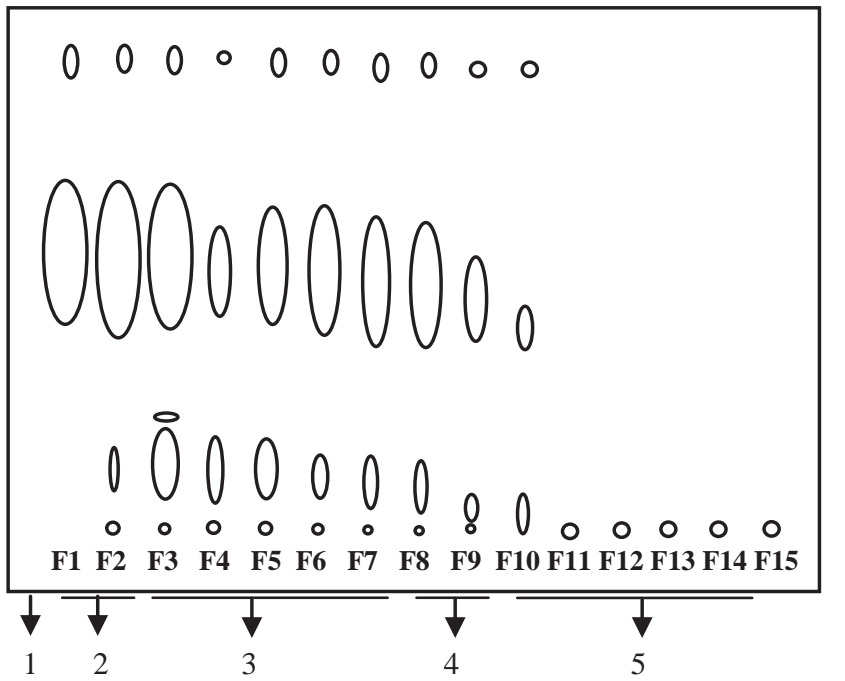

A

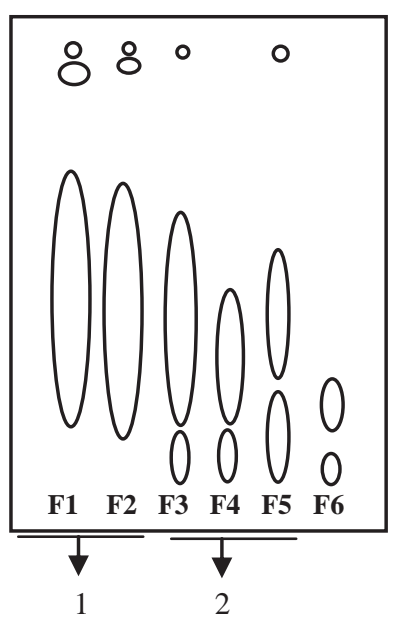

Figure 1. Representative diagram of TLC profiles obtained from methanol extract of Barugum (A) and chlorform extract of Maler (B). The numbers designated with arrows represent the combined fractions.

extracts of Yanggiru variety with yellow coloured did not show any anti-cancer activity indicating by $\mathrm{IC}_{50}$ values were higher than $500 \mu \mathrm{g} / \mathrm{ml}$.

Table 2. The $\mathrm{IC}_{50}$ value of chloroform and methanol extracts of buah merah on breast cancer cells (T47D)

\begin{tabular}{cccc}
\hline \multicolumn{4}{c}{$\mathrm{IC}_{50}(\mu \mathrm{g} / \mathrm{ml})$} \\
\hline \multicolumn{2}{c}{ Chloroform Extract } & \multicolumn{2}{c}{ Methanol Extract } \\
\hline Maler & Barugum & Maler & Barugum \\
139.72 & 174.88 & 352.72 & 132.83 \\
\hline
\end{tabular}

\section{Isolation of active portions from Barugum} and Maler extracts

The fractionation of methanol extract of Barugum yielded five combined fractions (Figure 1A) and directly subjected to cytotoxic assay. Whereas the fractionation of the chloroform extract of Maler resulted two combined fractions (Figure 1B). But due to the high similarity between the two combined fractions on the TLC profile therefore these fractions were again combined. Further separation was done using preparative TLC.

Bioassay guided fractionation of Barugum. Cytotoxic assay of the combined fractions of Barugum showed that the most toxic sample was the first combined fraction having an activity to allow viability of $16.43 \%$ of breast cancer cells at $250 \mu \mathrm{g} / \mathrm{ml}$. Result of the cytotoxic assay could be seen in Table 3 .

The potent combined fraction of Barugum was subjected for preparative 
Nuriningtyas et al.

TLC. The TLC profile showed that the fraction could be divided into two portions; upper and lower portions. Each portion was dissolved in chloroform : methanol $=9: 1 \mathrm{v} / \mathrm{v}$. These two portions were used for further analysis together with other portion resulted from Maler extract.

Table 3. Viability of breast cancer cells (T47D) after treated with combined fractions of Barugum at single dose $250 \mu \mathrm{g} / \mathrm{ml}$

\begin{tabular}{cc}
\hline Combined Fractions & Cell Viability (\%) \\
\hline 1 & 16.43 \\
\hline 2 & 121.76 \\
\hline 3 & 109.13 \\
\hline 4 & 88.95 \\
\hline 5 & 108.64 \\
\hline
\end{tabular}

Bioassay guided fractionation of Maler. The result of preparative TLC of Maler extract showed that the profile can be divided into 3 portions; upper, middle, and lower portions. Based on the bioassay monitoring of these three portions, the middle portion was confirmed as the potent portion (Figure
I.J. Biotech.

2). This was shown by the lower $\mathrm{IC}_{50}$ value of the middle portion compared to the upper and the lower portions (Table 4).

Table 4. TheIC ${ }_{50}$ value of three portions obtained from TLC preparative of chloroform extract of Maler on breast cancer cells (T47D)

\begin{tabular}{cc}
\hline $\begin{array}{c}\text { TLC Preparative } \\
\text { Portions }\end{array}$ & IC $_{50}(\mu \mathrm{g} / \mathbf{m l})$ \\
\hline upper & 170,61 \\
\hline middle & 117,15 \\
\hline lower & $>500$ \\
\hline
\end{tabular}

The middle portion of the Maler was further fractionated by VLC using 9 eluents. The TLC profile of these 9 fractions were documented. The fractions with the similar profiles were combined giving 6 combined fractions (Figure 3). Based on the result of TLC monitoring there were only 4 combined fractions including 2,4,5 and 6 used for further bioassay.

Comparison of cytotoxicity between Barugum and Maler. The two portions of preparative TLC of Barugum and these four
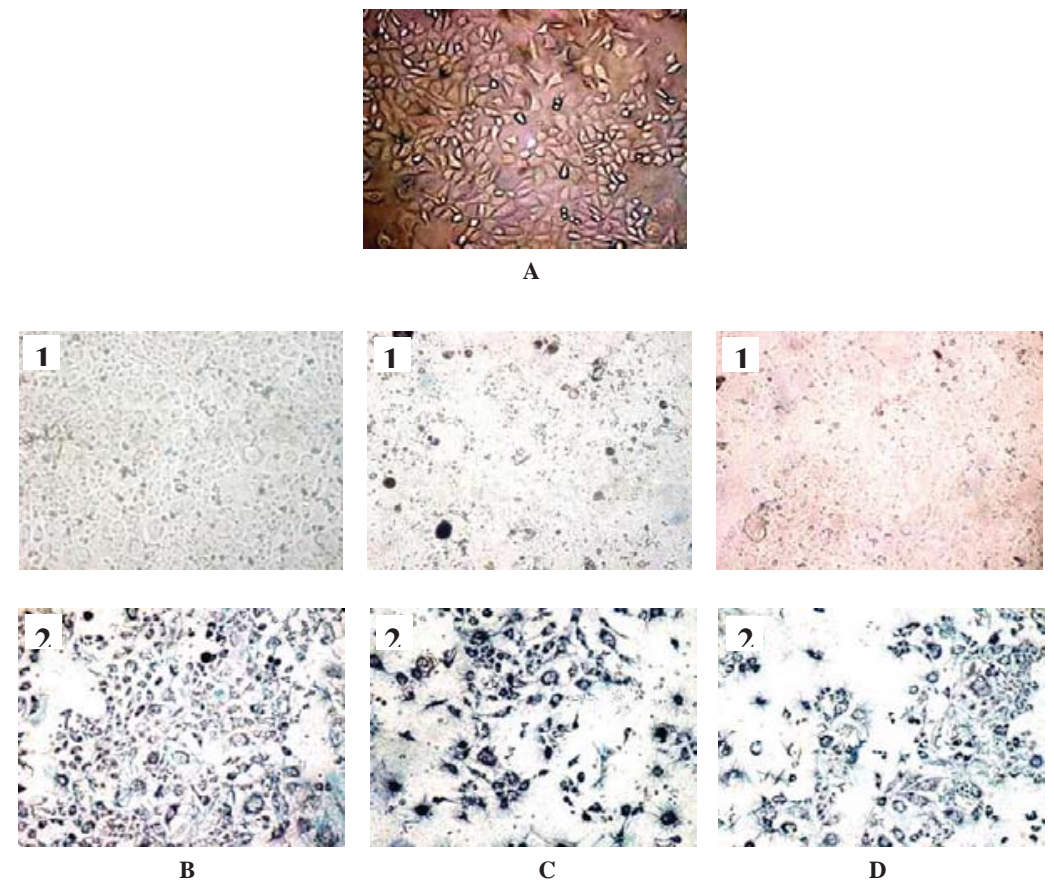

Figure 2. Breast cancer cells (T47D) morphology treated using three portions of chloroform extract of Maler $(10 \times$ 10 magnification) A: control, B, C, D: treated with portion solution. (B: upper, C: middle, D: lower).1: before MTT treatment, 2: after MTT treatment. 


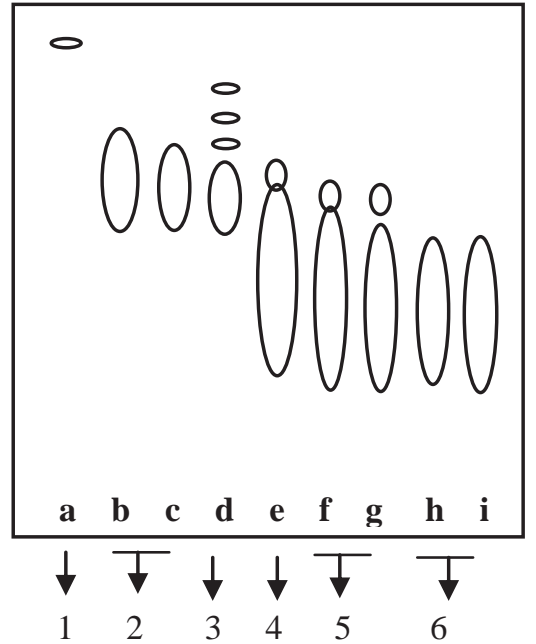

Figure 3. Representative diagram of TLC profile of 9 toxic fractions of chloroform extract of Maler. The numbers designated with arrow represent the combined fractions.

combined fractions of Maler as well as the commercial medicine, doxorubicine were evaluated their activities using MTT assay on breast cancer cells (T47D) (Table 5).

Table 5. The $\mathrm{IC}_{50}$ value of two portions derived from TLC preparative of Barugum, five combined fractions of Maler on breast cancer cells (T47D) and Doxorubicin

\begin{tabular}{|c|c|c|}
\hline $\begin{array}{l}\text { Varieties/ } \\
\text { Sample }\end{array}$ & $\begin{array}{c}\text { Combined } \\
\text { Fractions / portions }\end{array}$ & $\mathrm{IC}_{50}(\mu \mathrm{g} / \mathrm{ml})$ \\
\hline \multirow[t]{4}{*}{ Maler } & 2 & $>500$ \\
\hline & 4 & 37,15 \\
\hline & 5 & 38,54 \\
\hline & 6 & 25,70 \\
\hline \multirow[t]{2}{*}{ Barugum } & upper & $>500$ \\
\hline & lower & 104,61 \\
\hline Doxorubicin & & 41,68 \\
\hline
\end{tabular}

The result of this cytotoxicity showed that Maler variety possesses potent anticancer activity on breast cancer cell line (T47D) having lowest $\mathrm{IC}_{50}$ value of $25,7 \mu \mathrm{g} /$ ml. This $\mathrm{IC}_{50}$ was lower than Doxorubicin with $\mathrm{IC}_{50}$ value of $41,68 \mu \mathrm{g} / \mathrm{ml}$. The potent combined fraction was further subjected to TLC.

\section{Identification of Toxic Compounds Classes}

The most toxic combined fraction was analyzed by TLC followed by spraying using many detector reagents to identify the class of the toxic compounds. According to the spots obtained, it showed that the toxic compounds were terpene (Table 6).

\section{Discussion}

Secondary metabolites are known for their diversity. This can be observed between species or even within species. This diversity of secondary metabolites within species was well presented in this study. Three different local varieties of buah merah showed different cytotoxicity on breast cancer cell lines. The order of varieties of buah merah containing the most potent compounds was Maler, Barugum and the last was Yanggiru which have no anti-cancer activity. As Thorne (1975) stated that secondary metabolite could be used as chemotaxonomic characters and had a considerable impact on plant systematics. It could be used for identification and classification of flowering plants into a taxon because of the distribution of secondary metabolites is specific in certain species.

Table 6. The TLC result of the potent combined fraction of Maler

\begin{tabular}{lllc}
\hline \multicolumn{1}{c}{ Detector Reagents } & Bioactive Compounds & Spot Colour & Compounds Analyzed \\
\hline UV $\lambda 254 \mathrm{~nm}$ & Conjugated bonds & black & Positive $(+)$ \\
UV $\lambda 366 \mathrm{~nm}$ & Conjugated bonds & green fluorescence & Negative $(-)$ \\
Dragendroff & Alkaloids & orange & Negative $(-)$ \\
Sitroborat & Flavonoids & yellow & Negative $(-)$ \\
Ammonium vapour & Phenolic compounds & yellow & Negative $(-)$ \\
Vanilin sulphate & Terpenes & purple-brown & Positive $(+)$ \\
Cerium (IV) sulphate & Terpenes & brown, purple, purple-brown & Positive $(+)$ \\
Lieberman-Burchard & Triterpenes & blue dark & Positive $(+)$ \\
\hline
\end{tabular}


Most of bioactive compounds isolated from plants do not have cytotoxic activity, so called chemopreventive compounds. Chemoprevention could be described as a compound that prevents, inhibits, and normalizes carcinogenesis or prevents invasive cancer development (Meiyanto et al., 2005). Even though, according to Moeljopawiro et al. (2007), extract of buah merah have cytotoxic effects on breast cancer cells (T47D) and colon cancer cells (HT-29). Chemopreventive compounds are more selective than cytotoxic compounds on cancer cells because chemopreventive compounds have specific molecular targets (Meiyanto et al., 2005). Their targets are to inhibit carcinogenesis, cell cycle and angiogenesis.

Chemopreventive compounds could not be applied solely for cancer therapy. They can only be used as a supplement to prevent cancer development (Middleton and Kandaswami, 1993). These compounds are very useful in increasing immunity, reducing toxic risk, and lowering cytostatic therapy dose, thus lowering side effect of cytostatic therapy. In addition, the chemopreventive compounds also lowering cancer incidence and risk caused by cancer. Therefore, therapy using combination of cytostatic and chemopreventive compounds gives more effective and efficient results.

Results in this research indicated that extract of buah merah might not only as chemopreventive compounds but also have cytostatic activity. It's showed by the lower $\mathrm{IC}_{50}$ value of the combined fraction of Maler compared to the medical cancer drug, Doxorubicin. Futher study to understand how bioactive mechanism of the inhibition of the buah merah is needed.

The class of bioactive compounds obtained that have cytotoxic activity on breast cancer cells were terpenes. Terpenoids are the most abundant secondary metabolites that have various molecule structures. Most of the terpenoids are of plant origin; however, they are also synthesized by other organisms, such as bacteria and yeast as part of primary or secondary metabolism. They function as phytoalexins in plant direct defense, or as signals in indirect defense responses which involves herbivores and their natural enemies. Therefore, most of scientists think that terpenes have more ecological than physiological functions. Whereas diterpenes have a physiological function as a plant hormone, gibberellins (Wink, 2003)

Many reported studies have demonstrated the cytotoxic effects of various terpenoids against proliferation, growth and invasion of a variety of liver cancer cell lines. The mechanisms of anti-cancer activities varied including the increase of the apoptotic cell death process and reactive oxygen species (ROS) generation, increase in the tumour suppressor gene $p 53$, apoptotic proteins, such as caspase-3, and -9, cytochrome $c$ (cyt. c), and p38 protein expression (Huang et al., 2008), so that in India and China, terpenoids become the largest group of phytochemicals that are currently being explored as anticancer agents in clinical trials (Thoppil and Bishayee, 2011).

\section{Conclusions}

The result of this study showed among 3 varieties of buah merah, Maler variety possesses the most potent anti-cancer activity on breast cancer cell line followed by the Barugum variety. The Yanggiru variety having yellow color, did now show any anticancer activity. The class of the toxic compounds on breast cancer cells (T47D) were terpene.

\section{Acknowledgement}

We thank Ir. Afrizal Malik, M.P. and the villagers of Sentani, Papua for the buah merah. We also thank Mr. Sukiran, Mr. Iswahyudi, and Mrs. Rumbi for their laboratory assistance. This work was supported by Universitas Gadjah Mada and by Agriculture Department of Indonesia.

\section{References}

Anonim, 2005. Buah merah dan Manfaatnya. http://www.trubus-online.com. (diakses mei 2006) 
Cragg, G.M., and D.J. Newman. 2001. Natural Product Drug Discovery in the Next Millennium Pharmaceutical Biology. 39,8-17

Hedenfalk, I., Duggan, D., Chen, Y., Radmacher, M., Bittner, M. and Simon, R., 2001. Gene-Expression Profiles in Hereditary Breast Cancer. N Engl J Med., 8(344), 539-548.

Hortobagyi, G.N. 1998. Treatment of Breast Cancer. N Engl J Med., 14(339), 974-984.

Huang, J., Wu, L., Tashiro, S., Onodera, S., and Ikejima, T. 2008. Reactive oxygen species mediate oridonin-induced HepG2 apoptosis through p53, MAPK, and mitochondrial signaling pathways. $J$ Pharmacol Sci. 107, 370-379.

Longnecker, M.P., Newcomb, P.A., Mittendorf, R., Greenberg, E.R., Clapp, R.W., and Bogdan, E.F., 1995. Risk of Breast Cancer in Relation to Lifetime Alcohol Consumption. J Natl Cancer Inst., 87, 923-929.

Madigan, M.P., Ziegler, R.G., Benichou, J., Byrne, C., and Hoover, R.N., 1995. Proportion of Breast Cancer Cases in The United States Explained by Wellestablished Risk Factors. J Natl Cancer Inst., 87, 1681-1685.

Meiyanto, E., Jenie, R.I., Rahmi, F., and Septisetyani, E.P. 2005. Aktivitas Antikanker Minyak Buah Merah terhadap Sel Kanker Plasma Darah, Sel Kanker Payudara, dan Sel Kanker Leher Rahim. Final Report. Gadjah Mada University, Bernard T. Wahyu Wiryanta

Middleton, E., Jr., and Kandaswami, C. (1993) The Impact of Plant Flavonoids: Advances in Research Since 1986. London: Chapman and Hall

Moeljopawiro, S., Anggeliam M.R., Ayuningtyas, D., Widaryanti, B., Sari, Y., and Budi, I.M. 2007. Pengaruh Sari Buah Merah (Pandanus conoideus Lamk.) terhadap Pertumbuhan Sel Kanker Payudara dan Sel Kanker Usus Besar. Berkala Ilmiah Biologi, 6, 121-130.
Mosmann, T., 1983. Rapid colorimetric assay for cellular growth and survival: Application to proliferation and cytotoxicity assays. J. Immunol. Meth. 65, 55-63

Thoppil, R.J., and Bishayee, A., 2011. Terpenoids as potential chemopreventive and therapeutic agents in liver cancer. World J. Hepatol. 3(9), 228-249

Thorne, R.F., 1976. A phylogenetic classification of the Angiospermae. Evolutionary Biology, 9, 35-106.

Wink, M., 2003. Evolution of secondary metabolites from an ecological and molecular phylogenic perspective. Phytochemistry, 64, 3-19 